\title{
Hearing Voices of Care: \\ For a More Just Democracy?
}

\author{
Alessandro Serpe \\ University G. d'Annunzio of Chieti and Pescara, Italy \\ alessandro.serpe@unich.it \\ Received 18 July 2018; accepted 11 January 2019; published 30 June 2019.
}

\begin{abstract}
The purpose of this paper is not to provide an overall picture of care ethics, but, rather, to reflect upon the concept of care, which has gained significance in particular scientific contexts. Undoubtedly, the importance of the subject of care represents a challenge on the level of fundamental philosophical positions and a diversified look into the occurring forms of the psychological and social suffering, dependency, and vulnerability. I will shed light on tenets that are considered central to the care ethics and that have led to the setting up of the relationship between care and democracy. By introducing the basic aspects of Carol Gilligan's and Joan Tronto's theories, I will emphasize their vocation to be politically relevant. A discussion on the relationship between care and justice on the one hand, and needs and rights on the other, will follow. Can hearing voices of care make democracy more just? How can care ethics provide a concrete support for democracy? On the political level, care ethics builds on the assumptions of the necessary relatedness and equality between individuals who are decisive in the light of the welfare state perspective. Upon closer examination, one may see that the setting up of these relationships is not new to the liberal perspective. Liberalism is historically rooted in the fundamental interconnection between freedom and equality. Virtues such as care and meekness can be formulated in the language of politics, but they still remain unpolitical. On the one hand, engaging in a critical reflection upon such virtues might be an indispensable measuring instrument for distinguishing a good democracy from a bad one. On the other hand, care ethics does not prove to be a real alternative to the ethics of justice. In this regard, care ethics seems to show its feet of clay.
\end{abstract}

Keywords: care ethics; democracy; care; meekness; justice; rights; needs. 


\section{Introducing the Subject}

In spite of its young age, care ethics has been given much attention. Both in literature within bioethics, general, moral, political or legal philosophy, and in the fields of developmental psychology, sociology, pedagogy, and social services research, care has come into being as a subject for discussion. One may wonder why care has gained so much significance, deserving detailed considerations in all these particular contexts. Care has a certain dependence and univocal connections in relation to controversial philosophical, moral, legal, political or similar questions. In theoretical respects, it is not very reasonable to assume absolute boundaries in thought. For an apt picture, it is healthy to search for intertwined relationships between different areas of the application of the said concept.

Importance must also be given to the diffusion and weight of the topic of care, which represents, for one thing, a challenge on the level of fundamental philosophical positions that have been roundly endorsed for all sorts of reasons for several decades. For another thing, what is significant is the political, economic and legal scenario connected to the exiting new technologies, which is changing rapidly everywhere, bringing with it the need for many changes. Local and regional dimensions of multi-faceted transformation seem to overwhelm our lives as they come in waves, repeatedly testing our - and the world's ability and willingness to ride them. If, on the one hand, globalisation is meant to deliver packages of universal benefits and increase "the intensification of worldwide social relations" (Giddens, 1990, p. 64), on the other hand it leads individuals to pervasive loneliness and a feeling of disconnection. Therefore, globalisation raises new forms of psychological and social suffering, dependency, and vulnerability.

Restricting the matter to the political domain seems to provide a fairly poor awareness of the subject in question. Traditional concepts may become too loose to provide insight into actually occurring patterns, and so they require a fresh look. Substantial ethical questions have led the theory of justice to a further discussion and they grouped the concepts in a different way, allowing for a new perspective. In the occurring debate, there are indeterminate boundaries for what is categorised as 'care'. For the present discussion it is neither necessary to draw such boundaries nor to capture the whole sophistication and nuances in the professional research on ethical care. For now, it is sufficient to shed light on some central tenets that are considered significant in the care ethics for the setting up of the relations between care and democracy. This will be illustrated by means of a descriptivealbeit not merely uncritical-representation of the roots of the ethics of care.

I will first emphasise some basic tenets of Carol Gilligan' and Joan Tronto's theories by focusing on their vocation to be politically relevant. Later, I will discuss the relationships between care and justice on the one hand, and needs and rights on the other. These topics will be discussed in connection to, and with the aim of, bringing out and pinpointing some conclusive lines of criticism. 


\section{Gilligan's Voices...}

A fundamental contribution to the core of the concept of care was made by Carol Gilligan in her book In a Different Voice (Gilligan, 1982). She linked her discussion in moral psychology with moral philosophy and focused mainly on the question of how moral development rests on gender differences. She assumed that central parts of moral philosophy and many analyses in evolutionary psychology were misleading in that they failed to recognise the distinctive feature that lies in the female moral judgments during adolescence. Gilligan linked her discussion more generally to criticism towards Lawrence Kohlberg and Jean Piaget's theory, according to which a moral adult agent is capable of taking an impartial and detached perspective, and reach decisions correspondingly in a manner that rests upon the construction of what one may term, after Immanuel Kant, the noumenic subject. In particular, Kohlberg, who is a Harvard psychologist and whose model was evidently inspired by Kantian concepts of moral autonomy and reason, believes that a moral action can be explained with reference to levels and stages of moral development (Kohlberg, 1958; 1976; 1981). The author distinguished between three levels of morality (preconventional morality; conventional morality; postconventional morality) and divided each of them into two sub-stages. In so doing, he explained that while adolescent males score at stage four ('law and order orientation') — which is characterised by a higher level of abstraction whereby they follow the rules as an instance of their duty, judging the morality of an action on the basis of law and order-females tend to stop at stage three ('good boy-nice girl orientation'), which is characterised by 'interpersonal relationships' as criteria of judging the morality of an action. One important implication is that while males move on to the next postconventional level that is concerned with universal principles whereby their moral actions are 'social-contract' and 'universal ethic principles'-oriented (the fifth and sixth stages of the third level), the female moral reasoning is restricted to a sort of 'feminine goodness', which is inspired by a deep concern in helping and pleasing others rather than in conforming their moral action to transcend ultimate principles (Gilligan, 1982).

Gilligan considers it important, however, to maintain the difference between male and female moral reasoning, though her analyses lead to results which diverged from that of Kohlberg's. The crux of the matter is not an alleged female moral inferiority, but, rather, a female specification due to two different modes of experiences which are neither comparable nor subordinated to the moral models developed by males. Thus, different views of the world, different modes of perceiving the morality, different modes of experiencing conflicts and solving moral dilemmas must be taken into consideration when describing the differences in male/female moral reasonings. The best overview of the crucial loci at which moral differences occur is provided by the illustration of a case-study regarding the eleven-year-old children, Jake and Amy, in connection to the well-known Heinz-dilemma (Gilligan, 1982, pp. 28, 72). Should Heinz steal a drug, which he cannot afford, in order to save his ill wife's life? 
Studying the answers of the two children, Gilligan did not discover-unlike Kohlbergthat the reasons purported by them portrayed a gendered moral development linked to people's age growth. The children came up with different solutions; while Jake regarded the said moral dilemma from the standpoint of abstract and hierarchical principles and rules, Amy did not place any emphasis on abstract calculations, so her solution to the moral dilemma felt properly outside the domain of logical deduction. Her answers provided more open evaluations made not in an anatomical or excluding terms, but in terms of conflicting responsibilities and relationships over time (Gilligan, 1982).

The distinctive characterisation in the structure of the male/female moral reasoning can contribute to explaining that the male ethics, by resting upon the principles of justice and equality, represents a morality of rights. The female ethics speaks with a different moral voice. Justice and hierarchical order are not laid down as concept criteria of the female ethics, but it is rather contextual considerations, interpersonal connectedness, empathy, and care for others that are the moral bases instead. In other words, in real-life moral conflicts the female reasoning is care-based.

Such a mode of analysis not only sheds light on the tension between justice and care in moral reasoning, but it can also be regarded as exemplifying two very distinct normative ethical theories, namely the ethics of rights and the ethics of care (see sections 5 and 6 respectively). At this point, I should also note one significant divergence between Gilligan's and Kohlberg's views. Gilligan brings into focus the fact that each moral voice turns to be complementary in moral maturity. With full psychic maturity, men and women reach a sort of moral wholeness that manifests in the ability to integrate both voices. In particular, while the morality of rights is rooted in the claims of equal respect and fairness, the ethics of responsibility relies on the acknowledgment of differences and needs through compassion and care. The integration "is articulated through two different moralities whose complementarity is the discovery of maturity" (Gilligan, 1982, p. 165).

\section{3. ... and Later}

From the 1980's, care ethics has been strongly associated with Gilligan's feminist work. In feminist literature, a vast number of theorists have shown a common point of departure in that, on the whole, they seem to agree with Gilligan's view. In general, they seem to share the idea that the moral imperative in women is an injunction to care as well as her definition of care as a "responsibility to discern and alleviate 'the real and recognizable trouble' of this world" (Gilligan, 1982, p. 100). For example, Nel Noddings put forward the question of care in more philosophical terms by maintaining that care ethics is "rooted in receptivity, relatedness, and responsiveness" (Noddings, 1984, p. 2). She presupposed and manifested Gilligan's image of the "network of relationships" (Gilligan, 1982, p. 30) between interdependent individuals, ones that rely upon attentiveness and emotional responding. The main points can be surmised from the following sentence: "Taking relation 
as ontologically basic simply means that we recognize human encounter and affective response as a basic fact of human existence" (Noddings, 1984, p. 4). In Noddings's discussion, the emphasis is put on the fact that the anthropological and moral perspectives that ontologically ignore or void the concepts of interdependence, reciprocity, and care lead to uncertainties and inconsistencies on the level of fundamental philosophical positions. Noddings's view is meant to answer the question as to what connections might exist between individuals in order for the human existence to be preserved and flourish. The author's claim, one that can be traced back to Gilligan's concept of care, is that caring is "relation in its most basic form, a connection or encounter between two human beingsa carer and a recipient of care, or cared-for" (Noddings, 1992, p. 15). For Noddings, ethical caring occurs when one (a recipient of care) is calling and another one (the carer) responds by recognizing the sense of moral duty that sustains each caring relationship.

What is behind such assumptions, and what constitutes the main thread in the debate in the post-Gilligan years, is the fundamental criticism of utilitarianism and the contemporary normative socio-political contract theories, whose origins can be traced back to the philosophical, anthropological, and political thought of Hobbes, Locke, Kant, and Rousseau. In particular, care ethicists hardly disapprove of the basic tenets of the contractual theory of justice as purported by Rawls, steming from Kantian moral theory, according to which all human beings, in their capacity of beings, act in conformity to the categorical imperative independently of particular features of the concrete action situation. Care ethics theorists explicitly reject the fundamental grounds of contractualism. On the one hand, they reject the concept of individual autonomous rationality that is intended as the exclusive motive for acting morally; on the other hand, the idea of the "original position" (in Rawls' s terms) or the "initial bargaining situation" (in Gauthier's terms) represents the point of departure for a mutual and impartial agreement among independent, rational, and fully cooperative individuals. Rising to a higher level of abstraction and operating with higher-order moral principles would lead to a total denial of the complexity of real experience. A high degree of reliance on abstract principles and rules as a basis for moral and political reasoning portrays the image of an autonomous independent agent equally interacting with others. The pernicious 'myth of autonomy' rounds off the unavoidable relatedness between individuals and the controversial fundamental unequal power occurring in their mutual relationships.

In connection with the said main thread characterising the ethics of care from 1980s and early 1990s, other tendencies and conceptualizations were brought up and strengthened in actually occurring analyses and argumentation. A common feature in care ethics theorists' critical inquiry is the focus on vulnerability understood as the fragility of human beings. The analysis of vulnerability as a necessary condition of all people's lives - one referring to physical and psychological susceptibility to denial, humiliation, loss, illness, and abuse - is closely linked to care ethics and feminist philosophy (see Casadei, 2012; Mackenzie, Rogers, \& Dodds, 2014). It is difficult to examine whether any categorisation of topics related to care ethics is exhaustive; it is also hard to draw any sharp boundary line between the areas of thought and academic subjects, and give any structured account of the equally widespread contributions. There is, however, no reason to categorically label 
the colorful variety of insights. In what follows I shall point out how care ethics turned out to be valuable for political and social theory.

\section{Beyond Moral Boundaries: The Political Turn}

From the 1990s, the trend in care ethics moved towards writers distancing themselves from an exclusively gendered approach when discussing questions related to care and justice. Not much later, Gillingan and Noddings also distanced themselves from such arguments when discussing the implications of care studies for social policy, culture, and politics (Gilligan, 1993, pp. ix-xxvii; Held, 1993; Gilligan, 2010; Noddings, 2010). The decisive thing was how the main tenets of care ethics might have contributed to changing people's more general attitude, from regarding care as a private normative enterprise to regarding care as a public normative enterprise. In parallel with this change, there has been a derived political change in the specification and associations that accompany the word 'care'.

From the perspective and topic of the article herein, many central aspects of the new turn in care ethics approach can be described starting from, and in relation to, Joan Tronto's seminal work, i.e. Moral Boundaries: A Political Argument for an Ethic of Care (Tronto, 1993a). It must be said that this work is a fairly solid basis for further development, revision, and rethinking of care and its social and political impacts within the public realm. When emphasising care ethics as a tenable alternative to justice-based liberalism and when assuming that it will at any rate be significant as a normative pattern and method of analysis, it should not be gathered that care is merely private expression of interiority, one detached from care-public practices; rather, it has to be included in a more overall political phenomenology. With an increased awareness of different areas of the concept application, a vast number of scientific contributions are present in care research contexts, in which they are combined with other topics, thus giving rise to significant insights in the fields of women's rights, labor law, political citizenship, welfare policy, international relations, or global political economy.

In the conceptual framework of Moral Boundaries, Tronto reminds the readers of Gilligan's critique of Kohlberg's stages of moral development theory, and regrets the fact that the author did not purport any decisive arguments for contrasting the excessive class-gendered elitism and the hierarchical-social order abstractism. On closer examination, Gilligan's critique proves little or no resistance to the reduction of social exclusion by mistakenly bringing the logic of power and the gendered-oriented ethics together. As Tronto writes, "Gilligan did not disturb the basically exclusive logic of Kohlberg's theory" (Tronto, 1993a, p. 63). Tronto warns of the dangers of any form of biological essentialism tacitly assumed when discussing care ethics from the gender perspective. The essential thing is to be aware of the factual dis/similarities between genders; there is, however, no need to draw conceptual boundaries among and between them. The reduction of care ethics to the feminist question might lead to strengthening the historically infused bias, 
increasing women's and ethnic minorities' vulnerability to social stereotype threats. Correspondingly, care is best understood as the all-human beings fundamental practice, one that deserves full attention.

As Tronto puts it:

Care is nonetheless a universal aspect of human life. All humans need be cared for, though the degree of care that others must provide depends not only upon culturally constructed differences, but also on biological differences that human infants are not capable of caring for themselves, and that stick, infirm, and dead human need to be taken care of $[\ldots]$ care is not universal with regard to any specific needs, but all humans have needs that others must help them meet. (Tronto, 1993a, p. 110)

Therefore, care is not only an ideal moral concept, but, more importantly, it is also "a valuable political concept", one that "can serve as a political concept to prescribe an ideal for more democratic, more pluralistic politics" (Tronto, 1993a, p. 21). Care is a practice and, for Tronto, practice is a complex notion as "it is an alternative to conceiving of care as a principle or as en emotion". As the author continues, "To call care a practice implies that it involves both thought and action, that thought and action are interrelated, and that they are directed toward some end" (Tronto, 1993a, p. 108). Given that activity and aims are thought as having an interdependent argument value within the framework of the practice, for Tronto it is clear what is the basis for claiming that care is a political practice. This definition mirrors a more consciously universal view of care that contributes to further political development of the use of the concept itself. Indeed, the reference to 'practice' and 'political achievement' provides a more satisfactory explanation of her earlier notion of care that has previously been formulated with Berenice Fisher. In an essay written in 1991, they both recognised that the requirement of care/caring consisted in the fact that care is

[...] a species activity that includes everything that we do to maintain, continue and repair our 'world' so that we can live in it as well as possible. The world includes our bodies, our selves, and our environment, all of which we seek to interweave in a complex, life sustaining web. (Fisher \& Tronto, 1991, p. 40)

In that definition, care was defined in more general terms that allowed it to remain open to whether and how care ought to be resolved in public debate. Nevertheless, beyond that definition, the mode of language and argumentation used then was not disclaimed in 1993 and later on.

In Moral Boundaries, Tronto makes a number of pertinent remarks partly on the misleading biological essentialism and partly on the short-sighted gendered women's morality. In parallel with these remarks, she outlines a joint aspect of criticism towards Rawlsian's idealistic model of autonomy and equally involved moral agents as well as Habermasian inappropriate inclusion of the other, which is, however, more satisfactory from the socialpolicy perspective. Behind the curtains, a merger of Aristotelian and Nussbaum's foundation of ethics and politics can be found. Instead of Kantian detachment from reality due to aseptic pure reason, an interpretation of emotions within the realms of ethics and politics 
might be more adequate. ${ }^{1}$ More interestingly, when seen in a critical perspective, the intertwined conceptualisation of women's morality and the notions of 'sentiment' and 'common sense', which once emerged in the Western history of morality - in particular in the brilliant works of Scottish authors, such as Hume, Hutcheson, and Smith - brings out relevant features for a proper account of care ethics. In Tronto's view, models like those constructed by the Scottish illuminists acquire a strong intrinsic value for providing powerful insights into the drawing of an inclusive definition of care (Tronto, 1993a, pp. 25-59).

For the justification and determination of care ethics as a proper alternative to the views adopted within traditional ethics, the mutual relationships between ethics and politics must be taken into consideration. Thus, Tronto formed a set of challenges in order to overcome the moral boundaries that hinder the interdependence between human beings and disregard the political side of care, which has been fruitful in terms of pluralism and democracy. If this purpose is to be achieved, it is necessary to transgress the following boundaries: between ethics and politics, since power always demands a moral foundation; between particular and abstract/impersonal moral observer, as it comes from within the Kantian universalism advocated by contemporary authors with the serious danger that the (alleged) universal reason corresponds with the (alleged) universal morality, causing the (alleged) perfect equality; between the public and the private, as it is a relic of the Western tradition of male domination that, to a great extent, has given way to women being excluded from the public life by being relegated to a segregated position in the private, with a sole responsibility to the family. Tronto's suggestion is not "to defend the details of Aristotle's views, but to show that the supposedly natural separation of politics and morality is in fact an intellectual construction" (Tronto, 1993a, p. 184, n. 4). Indeed, care is "both a complex cultural construction and the tangible work of care. It is a way of making highly abstract questions about meeting needs return to prosaic level of how these needs are being met" (Tronto, 1993a, p. 124). Care is a complex practice process articulated in four phases that are analytically separated, but mutually interdependent. The four phases of caring are (Tronto, 1993a, pp. 105-108):

(1) Caring about: in this phase, someone or some group recognises an unsatisfied need to be cared for and acknowledges care as necessary;

(2) Taking care of: once an unmet need is recognised and identified, someone or some group determines how to respond to it by taking the responsibility for the caring process;

(3) Care-giving: in this phase, someone or some group is required to actual caregiving work aimed at satisfying the need;

(4) Care-receiving: once the care work is completed, there will be a care-addresser/s response and a dialogical feedback about the completeness and successfulness of the care work.

\footnotetext{
${ }^{1}$ For a more accurate picture of the role played by emotions and love in ethical and political life, see Nussbaum, 2001.
} 
Each phase corresponds to, and is aligned with, a peculiar ethical quality (four elements of care): attentiveness (1); responsibility (2); competence (3); responsiveness (4) (Tronto, 1993a, pp. 127-137).

With respect to the descriptive procedural side of care, the evaluative aspect comes into the picture. There is a presupposed choice of the fundamental value principle that has important consequences, for which the 'care-process' is to be considered as significant. Once the evalutative point of departure has been specified, the procedure can begin. This point is especially relevant in so far as care takes place at a democratic stage. Indeed, care is, for Tronto, the only way in which democracy can be fully achieved and preserved. This normative core finds expression in the fifth phase of care-process: caring-with, a more particular type of care that "requires that caring needs and the ways in which they are met need to be consistent with democratic commitments to justice, equality, and freedom for all" (Tronto, 2013, p. 23). Caring-with requires, then, that all the previous phases are fulfilled as well as it rests on people's expectation that "there will be such ongoing engagement in care processes with others" (Tronto, 2013b, p. 6).

Actually, the idea of linking care ethics with political systems, in particular with specific democratic practices, had already been conceived by another feminist writer. Selma Sevenhuijsen had complained that the debate on ethics of care represented a simplification in that many relevant matters had been omitted. Thus, the inclusion of ethics of care within the framework of democracy is to be seen as a specification. The new political concept of ethics of care is deemed as essential in that ethics of care can only work and be realized in a democratic context based on democratic citizenship and democratic institutionalised representation (Sevenhuijsen, 1998, p. 146). Tronto takes Sevenhuijsen's political revaluation of care into great consideration. In particular, Sevenhuijsen had identified an additional set of ethical qualities - plurality, communication, trust, and respect - that are necessary for caring democracy. Tronto is in line with Sevenhuijsen's way of placing care in a democratic society and identifying critical ethical qualities aligned with each phase of care. Nevertheless, she adds solidarity as an important virtue of caring-with (Tronto, 2013, p. 35).

In naming this mode of practice with the words 'caring with', Tronto brings out new aspects of 'care'. Caring-with denotes the fact that "to be a citizen in a democracy is to care for citizens and to care for democracy itself" (Tronto, 2013, p. x). Citizenship and caring intertwine as they are both an expression of both support and burden. Through their interplay, a different view on politics and democracy comes into being. The former one is not to be intended as belonging to the realm of economics, but to the realm of caring. Politics is not household, but, in being institutions, they both "rely upon bonds other than those that arise when people pursue their self-interest" (Tronto, 2013, p. xi). The latter one is not to be intended as a procedure, but as a form of governing that requires responsible citizens to engage in caring-with practices, i.e. to care about each other and for the values of freedom, equality, and justice (see Tronto, 1996). Care and politics embrace one another within democracy in so far as politics is not something which happens in the public while care does not happen in the private, as well as politics is not the masculine sphere and care 
the feminine sphere. Therefore, a reconstruction and redefinition of the concepts of care, democracy, and politics is necessary before one can continue the discussion and demonstrate their interdependence.

\section{The Intertwining of Care, Democracy, and Politics}

Firstly, with regard to care, if one can analyse more deeply why care is gendered, one would not fall into the public-private dichotomy. Unlike Lori D. Campbell and Michael Carroll (2007), who still associate care with the feminine on the basis of biological claim, and unlike those who provide a psychological explanation (see Chodorow, 1978, 2004) or a cultural interpretation of the traditionally dualized gendered roles (Gilligan \& Richards, 2009) or investigations in terms of knowledge (Plumwood, 1993), Tronto draws attention to two men's forms of caring which occur in society: public protection flourished in order to prevent harm, and production aimed at providing the material needs for the family (Tronto, 2013, pp. 70-82). Such an analysis shows how care is not confined to the female realm and that a sheer divide between the public and the private falls short. Furthermore, and more interestingly, care "needs a home" (Tronto, 2013, p. 37) in democracy and in democratic political theory.

Secondly, as to democracy, neoliberalism is brought into focus. In this regard, two main points should be illustrated. On the level of fundamental philosophical position, once again Tronto provides support for a view of the human being as a care-depending being contextualised in a network of social relations. Human beings are not (solely) rational actors endowed with autonomy and individual capacity to exercise choice. Moreover, choice is not freedom, not least equality and justice. In this regard, Tronto's view is in line with the one propounded by Stephen Holmes and Cass Sunstein, who also emphasise the 'illusion' of autonomy and freedom in the domain of law. Their criticism concerns the liberal myth of individual freedom as freedom from all forms of dependency and, in contrast, they point to the distinction between "freedom which is desirable" and "nondependence which is impossible" (Holmes \& Sunstein, 1999, p. 204). In Tronto's view, human life is not "the sum of an individual's own 'choices', for which he or she will be responsible. Care thus becomes entirely a personal and private matter; individuals make 'choices' about care for themselves and for those around them" (Tronto, 2013, p. 40). Tronto speaks of human beings and their decisional aspects neither in terms of a roughly unitary rational entity nor in terms of (solely) personal responsibility. What lies in her explicit rejection is quite clear: the neoliberal configuration of human being as homo oeconomicus driven by calculus of utility, benefit, and moral indifference. Homo oeconomicus is a market creature pursuing economic interests, submitting themselves to market metrics, and serving the market with personal responsibility and in the name of an alleged neutrality.

The second item to point out concerns the market. Are personal responsibility and market ideology enough for democracy? On the basis of the assumption, according to which human beings are caring beings engaged in an ongoing care processes with others, Tronto argued 
for the impossibility of neoliberal ideology to recognize problems of caring and democracy. Neoliberalism is not a descriptive economic theory, but an ethical system, "a disastrous worldview" which "sees people primarily as workers and consumers, who already have autonomy and clear ideas about their preferences" (Tronto, 2013, p. 38). Behind the curtain of neutrality, neoliberalism conceals the existence of vulnerable human beings and the power inequalities. There is, then, a structural incompatibility between "free market" and care (Tronto, 2013, p. 116), which causes insoluble problems. How can one adequately allocate caring responsibilities if one takes the ends of the market as the only ones compatible with neoliberal ideology? Neoliberal ideology rests blatantly on preferences and interests for "entrepreneurship, accumulation of wealth, driving prices for all goods as low as possible" (Tronto, 2013, p. 130), thus placing undiscussed and unwary emphasis on individualism. For these reasons, the neoliberal moral precept of "personal responsibility" represents a "false friend" for the democratic theory of care (Tronto, 2012, p. 38).

Given these two outlined points, democracy cannot be shaped by assumptions and evaluations based on the myths of free market and personal responsibility. From the point of view of care ethics, market is not neutral in allocating resources and goods, and setting equal power, while personal responsibility is profoundly antidemocratic in that it does not pay close attention to the relevant inter and intra inequalities between individuals and groups.

Thirdly, the subject of political life cannot be, ultimately, economy, free market, and personal responsibility. Politics is about the distribution and allocation of caring responsibilities in the view of a pluralistic reconfiguration of needs and care practices (Tronto, 2005, pp. 130-145; 2010, pp. 158-171; 2015). The point of conjunction between care and democracy with politics is well-formulated in the definition of politics as "a way to divide up responsibilities: who is responsible for caring what, when, where, and how" (Tronto, 2013, p. 46). As is apparent from the discussion above, caring-with is the essence of democratic life. Indeed, the essence of democratic politics is to affix responsibilities. In Tronto's words, democratic politics is about "assigning responsibilities for care, and ensuring that democratic citizens are as capable as possible of participating in this assignment of responsibilities" (p. 30). Good care in the political context is both personal and institutional. If, on the one hand, the market is not the model upon which public care social institutions should be shaped, on the other hand it is not even the model of family tout court. More specifically, while family presents certain elements of care-the purpose of care, a recognition of power relations, the particularistic instance of care-institutional care rests on the intersection of purpose, power, and plurality (Tronto, 2010, p. 166). Especially relevant here is the tension and the attention to human activities as particular and plural in the same breath and the purposiveness, namely the discussion of the ends of care. Politics is the public arena in which purposes, power, and plurality become visible and are debated, deliberated, and enacted (Tronto, 2010, p. 162).

In short, the interdependence between care, democracy, and politics can reasonably be seen also as an interplay between inclusive caring (in contrast with the neoliberal moral ideology 
of personal autonomy and responsibility), democratic caring practices (democratic assignment and distribution of caring and responsibilities), and democratic caring institutions (recognising the needs and determining ends and purposes at the level of politics) (Tronto, 2010, pp. 141-159). It is obvious that prior to discussing and determining the ends and the purposes of care, the understanding and the interpretation of needs is necessary. However, what needs can one talk about in this context? How should one determine needs? Who should determine needs? How should one prioritise needs? Who should be responsible for categorising and prioritising the needs? These questions bring up a difficult challenge for the ethics of care. Within the framework of democracy, the struggling political process is ascribed the greatest weight in negotiating and balancing needs and in resolving conflicts (see section 7). The aim for democracy and democratic politics is inclusive in that they have to make sure "that the voices of all people, not just the powerful, middle class, and so forth, are heard" (Tronto, 2004, p. 450).

Tronto's words are undoubtedly appealing and captivating even when the author discusses the relationships between needs and rights, and gets rid of the misconceived particularuniversal dichotomy (Tronto, 2004, pp. 448-449). Sticking with dichotomies is in itself a sign that these dichotomies are intended as normative. The same amount of normativity (and not value-neutrality) runs parallel and arises in Tronto's premises and argumentation on the whole. As far as care ethics is concerned, it builds on the choice of certain aspects of democracy and politics by attributing them with great weight. This is clearly visible in that Tronto shows no reticence in formulating some areas of concrete change in order to make sure that the idea of caring has a central place in private and public spheres. Therefore, she suggests "some directions of thought and action" (Tronto, 2013, p. 170): the nature of protection and market; the care-receiving processes; the values of caring in relation to market, institutions, and democracy.

I have so far provided a brief account of feminist care ethics and outlined in more detail the main points of Tronto's argumentation in relation to the interplay of care and democracy. In the following sections, I shall look at the relationship between care and justice as well as between rights and needs. Lastly, I will offer some final considerations with regard to democracy.

\section{Care versus Justice}

The debate on care and justice has been thriving for the last few years. In particular, the discussion has been placed in terms of a critical interaction between two conceptual frameworks rising from care and justice, namely the contextualised versus the decontextualised approach to ethical, political, and legal theory and practice. The feature of the distinction between care and justice is that care constitutes a conceptual corrective or at least an alternative model to justice. In this sense, care can replace or at least challenge vigorously the traditional ethical, political, and legal theories by shaping a distinctive normative approach to ethical, political, and legal issues. 
Various theories of justice downplay or ignore the possibility of distinguishing between care and justice and of finding a general criterion that would make it possible to provide a distinction or at least a more embracing account of care $^{2}$ (Palazzani, 2017, pp. 57-97). Liberalism expresses its preference for the individualistic anthropology. In this view, individuals are considered self-sufficient and autonomous. The sole values that society has to safeguard are individual values, such as life, freedom, and property. Not surprisingly, individual liberties are to be preferred to social solidarity so that it remains difficult to find any tenable justification for the theorisation and promotion of care. Care does not occupy any prominent space in the liberal thought as well as in the utilitarian view. For utilitarians, such a denial stems from hedonistic anthropology. What is behind this rejection is the fact that individual pleasure and convenience are interwoven with utility, and utility provides the general criterion for the morality of an action. Only those individual actions that can provide collective benefits or increase the utility more than alternatives can be considered just. Justice is measured through the calculation of the normative consequences of an action in terms of utility. In both versions of utilitarianism, i.e. act-utilitarianism and ruleutilitarianism, care is not thematised as it escapes from a direct utility calculation, whether the individual action is assessed in the light of its (useful) consequences or evaluated by the universal moral principle to 'maximize utility'.

In recent neocontractualism, John Rawls develops "a viable alternative to the utilitarian tradition" (Rawls, 2010, p. 150), departing from the idea of mutual disinterested rationality of the parties, which is manifested in the purely hypothetical situation of the original position aimed at setting up "a fair procedure so that any principles agreed to will be just" (Rawls, 2010, p. 136). Beyond the veil of ignorance, the parties insure the integrity of the mutual agreement on the conditional assumption that they have "a capacity for justice in a purely formal sense" (Rawls, 2010, p. 145), which makes it possible for them to adhere to the chosen principles. The institutional form of justice as fairness is given by two principles that would be chosen in the original position: "each person is to have an equal right to the most extensive basic liberties compatible with a similar liberty for others" and "social and economic inequalities are to be arranged so that they are both (a) reasonably expected to be to everyone's advantage, and (b) attached to positions and offices open to all" (Rawls, 2010, p. 60). The first principle is called by the author the "principle of greatest equal liberty". With regard to the second principle, Rawls speaks of (a) "the difference principle" and (b) "the principle of fair equality of opportunity". In choosing these principles, the rational parties undertake a maximin reasoning in the sense that they "think of the two principles as the maximin solution of the problem of social justice” (Rawls, 2010, p. 152). In particular, the difference principle is associated with the rule of maximum minimorum (abbr. maximin), according to which in an uncertain social situation the rational parties would maximize the minimum level of primary goods so that the distribution of income and wealth can be fair, if decently achieved. Rather than focusing on what is distributed, the Rawlsian

\footnotetext{
${ }^{2}$ For the reconstruction of, and comparison between, various theories of justice and various theories of care, see: L. Palazzani, 2017. It has been an inspiration for the formulation of this part of the article.
} 
model of justice as fairness takes into account a more equitable way of sharing in consonance with the principle of distributive justice. Even though care is not theorised, it is, however, reasonable to maintain that care is an assumedly necessary condition of justice.

The emphasis in the communitarian critique of liberalism and neocontractualism is placed on the anthropological tenets of individual self-sufficiency and autonomy, and on the devaluation of community in contemporary society. Correspondingly, communitarians such as Alasdair MacIntyre propose a more down-to-earth approach to moral agency and moral decision-making. On the model of Aristotle's concept of common good and virtues as moral excellences, MacIntyre describes how virtues shape the moral identity of an individual and how they constitute the grounds for an independent practical reasoning. In contrast with liberalism and neocontractualism, MacIntyre is concerned with rejecting the image of the self "detachable from its social and historical roles and statuses" (MacIntyre, 1984, p. 221), and embraces a social notion of virtue. The critical view on individualism is put forward with the following words: "I am born with a past; and to try to cut myself off from that past, in the individualist mode, is to deform my present relationships. The possession of an historical identity and the possession of a social identity coincide" (MacIntyre, 1984, p. 221). An oversimplified picture of the individual as an abstract self and the attachment to fundamental position in Kantian philosophy that underlies this simplification seems to cut the individuals away from their real lives and membership in communities. Virtues are central in MacIntyre's view not only to framing the individual moral identity and reasoning, but also to "sustaining those traditions which provide both practices and individual lives with their necessary historical context" (MacIntyre 1984, p. 223). This view presupposes the possibility and the carrying out of relatedness-conditions and care structuring as necessary criteria for a just society. Although care is not thematised, the merits of both neocontractualism and communitarianism consist in the inclusion of care as a necessary or at least presupposed concept criterion of justice.

The views that go under the name of 'ethics of care' may be grouped in two generations, according to how and to what extent care is built in connection to justice. As is apparent from the above analysis, the first generation of theorists claimed that care was a necessary and sufficient criterion of moral experience, central in women's moral reasoning and life practice, emotionally embedded and relegated to the inner space of family and private life. In such a perspective, justice is, in contrast, a (moral-legal) universal concept, central in men's moral reasoning and life practice, rationally embedded and referring to the outer public sphere. Despite their distinctive features, care and justice will often be incomplete without integration. As has already been said, Gilligan never claimed that women's careoriented moral reasoning was superior or better than men's justice-oriented moral reasoning. Nevertheless, although the author considered it more apt to focus attention on their integration or complementarity in view of moral development, she seemed to pull in the direction of pure distinction in the light of their peculiarities. Along similar lines, Noddings had interpreted the different characterisations of care and justice with the images of "mother's voice" and the "language of father" (Noddings, 1984). 
The second generation of care ethics theorists takes as a point of departure the most significant connection or complementarity and non-alternativeness between care and justice. Here, care and justice are gender-detached and they do not exemplify, correspondingly, the voice of women and the voice of men. The possibility of a close connection between the two types of "moral voices" has been cautiously purported by Virginia Held (Held, 2006). The interplay of care and justice has been purported more vigorously by Michael Slote, who argue that care ethics can provide a complete approach to action-guiding and decisionmaking processes (Slote, 1998; 2007). Moreover, this author's notion of “empathic caring”, consisting in the very experience of feeling and morally approving of another's caring (Slote, 2004, pp. 299-300; 2006, pp. 227-228) is also placed on the basis of the legislator's motivational relationship with the law (Slote, 2004, p. 303-304). Given these two points of departure, no discrepancy between care and justice comes into existence, and care, from having been relegated to the private domain, is now intended to complement the public sphere. The standpoint that scholars ought to take a closer look at a more intertwined connection between care and justice is provided by other interesting theorists, such as Claudia Card, Bill Puka, and Susan Okin. They undertake a more critical reading of the possibilities of the reciprocity of reason and feeling in moral reasoning as well as the mutual relation of care and justice within the public sphere. More particularly, Card and Puka attacked the Gilligan-inspired gendered ways of understanding care ethics, which, in their opinion, leads to a destructive slave morality hinged on the subaltern role of women in society, thus increasing their oppression in the working environments (Card, 1990; Puka, 1990; Okin, 2004). In so doing, the authors opened doors for a political concern of care, and applied the tenets of care ethics to public issues such as law, labor, and healthcare.

With increased awareness of the need for renovation of care ethics, and with more systematically academic works, Tronto's contributions may be considered as the most significant in answering the questions of what roles and relationships are possible for care and justice, and how it is possible to weave care into a democratic and pluralistic society. So far, I have sought to critically show Tronto's perspective and topics.

In the light of the views of the second generation of ethics of care, it is possible to claim that the constitutive interplay of care and justice may serve as a replacement for the unilateral (gendered) account of moral reasoning. Acknowledging distinctiveness of both concepts does not entail denying the possibility of interaction. This is especially true when one looks at care as a social and political practice. In the context of public policy, care serves as a means aimed at contrasting the excesses of a liberal or neocontractual view of self-sufficient and autonomous individuals, as well as facilitating the comprehension of human fragility, vulnerability, and need for interdependence. Justice serves as a means aimed at rationally distributing and sharing burdens, role, and competences. This would avoid both the risks of exploitation and mistreatment for the caregivers and the risks of power dominance or subordination for the care-receivers. 


\section{More Reflections on Care and Justice: Meekness and Care}

What emerges from the care ethics contributions is the prescriptive model. Care acquires such a strong intrinsic value that the considerations for an adequate description of facts are set aside. A common feature of the theories is that they claim that something called 'care' ought to be grounded in contemporary society.

The first question here is that, like any concept, the term 'care' has various denotations that lead to ambiguities. The ambiguity lies in the question about whether the definition that ' $\mathrm{X}$ is' refers to the word in the light of the actual language use and contexts, or to the phenomena behind the word. Without a doubt, the area of denotation of the term 'care' may vary in accordance to the linguistic usages and contexts. Care may swing from a weak area of meanings such as concern, empathy, solidarity, attentiveness, carefulness, and awareness to a strong area of meanings such as responsibility, vigilance, supervision, guarding, and protection. In addition, care may be used in 'everyday language' or in 'technical language'. Both usages may lead to contentious discussions as the former one is formulated more freely as sometimes lacking a systematic pattern, while the latter one refers to specific areas of application characterised by scientific knowledge from science to philosophy, politics, ethics, psychology, and other academic disciplines. With regard to historical origins of the term, one could say that care is a common term of the 'everyday language' and, at the same time, it has been theorised and used in various contexts to denote different objects. The origin of the term 'care' is Anglo-Saxon; in Italian 'care' may be literally translated as 'cura', or less literally with reference to the action of caring as 'il prendersi cura'. These few reflections merely exemplify the difficulties that any approach to care ethics reveal and that must taken into thought.

The difficulties arise when one sees care ethics as providing a general normative paradigm which, on the one hand (the first generation), schematises people's moral behaviour into a simple dyadic model which overlooks women's and men's peculiarities and the complexity of their moral reasoning; and, on the other (the second generation), provides normative value considerations hinged upon a subjective desire for reasonable and just society. Tronto clearly summarises her viewpoint when she says that "the ethic of care entails a basic value: that proper care for others is good, and that humans in society should strive to enhance the quality of care in their world 'so that we may live in it as well as possible"” (Tronto, 1995, p. 143). If one acts normatively in the exercise of care on the normative assumptions that 'care for others is good' and that 'humans in society should strive to enhance the quality of care', because this leads to living in the world 'as well as possible', then they ought to know first and foremost what care is and how it is felt within a determined society. What is decisive here is that if one takes care as a normative paradigm for the construction of a just society, they ought to have access to some invariant features characterising the society as a whole or a political community as a legal community, and provide concrete, more fixed points to hold onto (see, Bilancia, pp. 41-45). Otherwise there would be serious risks of falling into a mere parochial view imbued with favoritism, partiality, prejudice, and discrimination. 
Further considerations pose more questions. If one places the greatest weight on care as an intrinsic value of a good society, then how does one intersect care, a moral virtue constitutively linked to the private sphere of concern for others, with the liberal moral-legal values of tolerance, freedom, and justice that are linked to the public sphere? It is not easy to answer this question in general terms, but the question is well suited as a point of departure. Care is not a theory, but a value, a virtue (on care as virtue see Slote, 1998; Sevenhujsen, 1998; Rachles, 1999), a disposition, and a personal attitude, overlapping with other moral and legal concepts in order to be a proper practice. As all moral virtues, care may be seen as supporting the structure of a society. There is no doubt that a democratic and pluralistic society requires more than respect and tolerance, freedom and justice. Does democracy need virtuous members, or only just citizens?

In a short and refined essay titled "In Praise of Meekness" (Bobbio, 2000), the Italian legal and political philosopher Norberto Bobbio showed how virtues could be friends of democracy. He did not theorise care as a cardinal virtue for democracy, but his notion of mitezza, translated into English with the doubtful word 'meekness', might offer a relevant argument concerning this question. Although being a pre-political virtue, meekness can be an actiongoverning moderation virtue. For a better understanding of the complexity of meekness, Bobbio provided a conceptual set of closer meanings by drawing a line of analytical differentiation between strong and weak virtues. The former ones include all the virtues experienced and practiced by those who have power, lead, and govern, i.e. courage, bravery, audacity, prowess, liberability. In contrast, the week virtues include humbleness, moderation, modesty, innocence, and simplicity; these are features experienced and practiced by inconspicuous individuals, who will never have power and will never be able to lead and govern. Meekness belongs to the latter set of virtues and stands in opposition to arrogance, self-righteous posturing, aggressiveness, and greed. In Bobbio's view, these last are "virtues or vices depending on different interpretations characterising a political man" (Bobbio, 2010, pp. 37-39). The meek person 'lets others be themselves' without abandoning the fight. In this, the meek are different from both the submissive, who leave the battle because of fear or weariness, and from the humble, who act sadly in contemplation of their own impotence or weakness. In short, meekness borders the region of tolerance and respect for the ideas and lifestyles of others. Bobbio's consciousness of living in a violent society is well expressed by the figure of the meek person as non-violent and meekness as the refusal to exercise violence against anyone (Bobbio, 2000, pp. 26-35; Serpe, 2008, pp. 49-50). The characterisation of meekness as a virtue strongly opposed to mere violence and brute force is especially interesting in the light of care ethics. Bobbio explicitly states that "meekness has always seemed desirable to me precisely because of its femininity [...] the practice of kindness is bound to prevail when the city of women is realized" (Bobbio, 2000, p. 34). Meekness is a weak virtue - although it is not inferior or less appreciable - with a feminine nature due to its peculiarities of non-violence, relatedness, and care lato sensu. Moreover, the meek person nourishes the profound conviction the world will be better than the one they are unwillingly living in. As has been evident, the 
search and need for a moral anchorage in the great social and political upheavals of our contemporary society is common for all the second generation views on care ethics.

All these features designate meekness as the lowest political virtue, the other face of politics, "the most apolitical of virtues" (Bobbio, 2000, p. 28). In the Machiavellian or Schmittian views, meekness is exactly the opposite of politics. Bobbio's arguments are not against politics itself. Indeed, they are arguments against fanaticism, intolerance, violence, and lust for power. It is not a coincidence that Bobbio quotes Aristotle's Nichomachean Ethics, or Kant's Die Metaphysik der Sitten. More significantly, Erasmus' Education of a Christian Prince is crucial to his thought. Erasmus' ideals of gentle disposition and political moderation against religious fanaticism inspired by Christianity were embodied exactly in the virtues that Bobbio calls 'weak'.

Returning to the posited question, I might say that politics needs virtues as they constitute the substructure of a democratic society. At the same time, virtues are also significant aims and objects of investigation as they serve to look at the crude reality and the theoretical disciplines through new eyes. Bobbio puts it this way:

One cannot cultivate political philosophy without trying to understand what is beyond politics, or without venturing into the non-political sphere, and attempting to establish the boundaries between the political and non-political. Politics is not everything. The idea that everything is politics is simply outrageous. (Bobbio, 2000, p. 28)

Although virtues such as meekness and care can be formulated in the language of politics, they remain unpolitical. However, since they can be invoked as preconditions for nurturing a civil society, the engagement in critical reflection upon them is necessary for democracy and a theory of democracy. This formulation simply says that the requirement of determined virtues, whether meekness or care, ought to be satisfied in order for democracy to be a good democracy. At the same time it says nothing about what to attach to this requirement and how to satisfy and justify it. This is the crux of the matter: how can care ethics provide a concrete support for democracy? ${ }^{3}$

On a political level, care ethics builds on the assumptions of the necessary relatedness and equality between individuals, which is decisive from the perspective of welfare state. The said close connection between the two assumptions seems to distinguish the (new) ethics of care from the (traditional) ethics of justice. On closer examination, one may see that the setting up of these relationships is not new to the liberal perspective. As is well known, liberalism is a specific conception of the state, according to which the state has limited powers and functions. With regard to historical origins, one may agree that, although for

\footnotetext{
${ }^{3}$ However, the central real problem here is about the choice of ontological and epistemological premises: how can we justify the connection between non-empirical features (moral requirement) and an empirical phenomenon (political behavior)? For a proper development of the discussion, it is important which perspective one adopts. Such a sequence of thoughts and questions leads to the relationship between the law and ethics. This has been one of the most crucial and longstanding topics in the philosophy of law and legal politics, and an answer to this question is beyond the scope of this paper.
} 
different reasons, Locke, Montesquieu, Kant, Smith, Constant, Mill, and Tocqueville all professed severe criticism against the state in the name of a market economy and secularism. Liberalism fought strongly for emancipation from the economic, political, and religious power (Bobbio, 1995, p. 125, 2006; 2009). The history of liberalism is the history of civil liberties and political liberties. The philosophical outputs of Hobbes, Rousseau, and Kant determined the liberal concept of freedom: freedom is, for the modern thought, negative freedom. Furthermore, the anti-paternalistic and individualistic background emerged from the limitation of the exercise of power. At this point, significant relations between liberalism and democracy intertwine. Liberalism is the modern theory of the state, propounding the ideal of protection of individual liberties through the means of a democratic direct or indirect participation of individuals in political life. The core of rights are the pre-conditional civil rights and the political rights. Bobbio describes the interconnection between liberalism and democracy with the charming expression "natural continuation" (Bobbio, 2006, p. 47). A more comprehensive account has been given by Hans Kelsen who wrote that:

[...] modern democracy can not be separated from political liberalism. The main principle consists in the fact that democracy must not interfere in certain spheres of interests that belong to the individual and must be protected by law as fundamental human rights or rights of freedom. (Kelsen, 1998, p. 245)

These views show the peculiar strength of liberalism as the doctrine inspiring democracy and grounded on the recognition of certain freedoms necessary for the existence and the exercise of democratic power, such as freedom of opinion, assembly, association, press, and religion. One may say that the democratic state is not only a "natural continuation" of the liberal state, but it is also, and more importantly, its legal prerequisite. The democratic state does not exercise its power only in conformity to a mere principle of formal legality, but within the limits imposed by the constitutionally recognized and guaranteed rights of liberty (Serpe, 2015, p. 18).

Nevertheless, the liberal views on the ontological and axiological primacy of the individual over the group, owning the right to live, exercising freedom, and acting by their own judgment against public interferences, does not ignore equality. It is also not the case that liberal views claim that equality must be restricted for the good of liberty. Deprived of its emotive meaning, equality is a not a sufficient, but a necessary condition of justice. I consider Bobbio's account of equality and freedom to be especially insightful. In the author's opinion, equality is within the formal criteria of justice that are specifications of the maxim suum cuiuque tribuere. Equality is, then, derived from the principles of "all men are equal", "all men are equal before the law", "the law is equal for everyone". However, the content determination of such principles depends on egalitarian ideologies. Liberalism is, then, not the reverse or the antithesis of egalitarianism; it defines equality in terms of equal liberty of individuals. More thoroughly, Bobbio wrote that "liberalism [...] admits the equality of all not in all (or almost everything) but only in something, and this 'something' is usually the so-called fundamental, or natural, or, as we say today, human rights” (Bobbio, 2009, p. 36). The main reason why democracy has to be preferred to other forms of government is that 
democracy is the political system that permits the closest convergence between political and moral needs. This means that democracy always moves towards a moral ideal. As I have said earlier, the engagement in critical reflection upon virtues such as care, empathy, and solidarity is an indispensable measuring instrument for distinguishing a good democracy from a bad one.

In conclusion, in what has been outlined so far, there is a fundamental interconnection between freedom and equality according to liberalism. Liberalism favors democracy over other forms of government due to the role of freedom, and still does not ignore equality and care for others. Indeed, respect and tolerance are the key concepts of justice. In this regard, ethics of care does not prove to be a real alternative to ethics of justice. Though care ethics advances interesting reflections on empathic concern for others and manifests the demand of waning the ideals of individual autonomy and independence in order to better take care of the worst-off in society, and improve the welfare and wealth of all its members, there is no need to reconceptualize the Western liberal way of thinking about justice, democracy, and the language of politics in terms of empathy and care (Slote, 2015, pp. 5-7).

\section{Rights versus Needs}

The supporters of care ethics direct their attention to a further question that runs parallel and is conceptually linked to the said relations between care and justice, and freedom and equality. By sticking to dichotomies and with dyadic arguments, many authors ascribe weight to the differentiation between rights and needs. In literature, there are, on the one hand, those who claim that rights should be reconceputalized in terms of needs and that needs are the basis for rights in such a way as to constitute an alternative to rights. This is the viewpoint of Mark Tushnet, who pointed out some pragmatic and semantic reasons for this reduction. Firstly, he maintains that the capitalistic liberty-centered rhetorics of rights must be abandoned in favor of the full recognition of needs. As he puts it:

There do seem to be substantial pragmatic reasons to think that abandoning the rhetoric of rights would be the better course to pursue for now. People need food and shelter right now, and demanding that those needs be satisfied - whether or not satisfying them can today persuasively be characterized as enforcing a right—-strikes me as more likely to succeed than claiming that existing rights to food and shelter must be enforced. (Tushnet, 1984, p. 1394)

Secondly, his arguments involve semantic reasons in that rights-terms are unstable, indeterminate, abstract, and the use of rights language impedes "advances by progressive social forces" (Tushnet, 1984, p. 1364).

There are also those who claim that rights should not be reconceptulized in terms of needs and that needs are neither alternative nor complementary to rights. This is the view of Patricia Williams who, in combining the issues of race and rights, argued that the language of needs undoubtedly sounds more compassionate and "moving enough to have been called poetry, oratory, epic entertainment" (Williams, 1991, p. 151). Nevertheless, taking the history of black African-Americans as a test case into account, the language of needs 
"has never been treated by white institutions as the statement of a political priority language of needs" (Williams, 1991, p. 151). Indeed, it can turn out to be harmful. As the author continues:

For blacks, then, the battle is not deconstructing rights, in a world of no rights; nor of constructing statements of need, in a world of abundantly apparent need. Rather the goal is to find a political mechanism that can confront the denial of need. The argument that rights are disutile, even harmful, trivializes this aspect of black experience specifically, as well as that of any person or group whose vulnerability has been truly protected by rights. (Williams, 1991, p. 152)

Faced with àut/àut disputes, an intermediate solution is often the wisest choice. The subject in question is not easy, but my standpoint is in favor of not deviating too much from the language of rights and the way Westerners have thought of them, and a great weight that they ascribed to them. The more one deviates from the liberal model of democracy and rights, the greater the danger that one will have to deal with the new area of concepts. The history of rights is the history of bloody fights against abuse of power, brute force, domination, and oppression. The history of rights is also the history of very complex and wellreasoned theories, such as liberalism. Although nothing is ever truly unquestionable and unchallengeable, the theory of rights has been settled in the course of time for the enterprise to defend and safeguard fundamental demands of morality shared by all individuals.

As Jeremy Waldron has clearly pointed out, the language of needs is not less indeterminate and vague than the language of rights. In sentences like " $P$ needs $X$ in order to $Y$ ", the focus falls on the specification of the aim Y; is $\mathrm{Y}$ "an appropriate matter for political concern"? (Waldron, 1996, p. 92). Or, in the categorical sense of 'need', in sentences like "P needs X", the focus falls directly on the specification of the condition X; how does one assess that $\mathrm{X}$ is a necessary condition for $\mathrm{P}$ ? Since all the political concepts are incomplete and more requirements are often put forward for determinacy, there is always a reason to claim that the language of rights is more determined. To assert that " $\mathrm{P}$ has a right to $\mathrm{X}$ " is to acknowledge that somebody is entitled to a correlative duty or responsibility. Or, at least, it is easier to identify the correlated duty bearer. In relation to this point, Wesley Newcomb Hohfeld's table of correlatives ought to be taken in mind (see Serpe, 2012).

Moreover, correlativity to duties is not the only feature of rights. Although rights have traditionally been perceived as expressing the moral demand of negative freedom or freedom from state interferences (such as political rights or freedom rights), some rights do require forms of action, intervention, and assistance from others. Thus, rights are correlated not always to duties of negative action or of non-interference, but to duties of positive action. Waldron takes the contractual law as a paradigmatic case (Waldron, 1996, p. 99). Even in the case of voting, the right is correlated to a duty or responsibility of positive action. In this regard, he says that:

[...] in the case of voting rights, for example, the responsibility is to set up and maintain mechanism of popular decision making in which each individual will have en equal voice [...] respecting the right means going out of one's way to give that action meaning in the context of a flourishing democracy. (Waldron,1996, p. 100) 
Duties of positive actions are more clearly expressible as a set of necessary conditions of a legal norm when one looks at the economic, social, and cultural rights. The transformations of the contemporary society due to the growth of the social welfare and welfare state have led to the metamorphosis of the concept of law and its functions. From law considered as a mere tool of 'social control' and legal norm as structurally composed of a legal fact conditionally related to a negative sanction as its consequence, law and legal norms have come to be perceived as tools of 'social direction'. In his discussion of the structure and functions of the law in legal theory, Bobbio used the expression 'promotional function', with which he meant the action carried out by the law with its tools of 'positive sanction'. It is no longer the time to look at the legal system from (only) a repressive and protective angle. The law does not only act through 'disincentives' (penalties, amends, reparations, compensations, etc.) that are aimed at preventing or hindering socially undesirable acts, but it is also involved with 'incentives' (recompenses, facilities) that are aimed at promoting the fulfillment of socially desirable acts (see Bobbio, 1969, pp. 13-32; 1977, pp. 7-9).

\section{Conclusion: Feet of Clay?}

The ethics of care is not hardly alone in having the view of defending and promoting welfare state and pursuing the effectiveness of social rights. Most importantly, it is by no means alone in holding the view that the autonomous being is not an isolated monad, and that the interplay of autonomy and morality is manifested in their being social and a part of the humanity. It should be remembered that the early liberal thinking never ignored or under-regarded the 'humanity', the 'mankind', and the 'common good' as duties imposed on all human beings. It could be refreshing to dust the most treasured philosophical works off; thee include Kant's Groundwork of the Metaphysic of Morals, Vico's On the Study Methods of Our Time, and Locke's Two Treatises of Government. In this regard, care ethics seems to show its feet of clay.

Both perspectives, i.e. the ethics of needs/care and the ethics of justice/rights, are no doubt compatible since rights can be efficient tools of justice for promoting aids as well as they can aid care through the means of positive action. The emotional gaze that the ethics of care turns towards pressing issues, such as social rights, healthcare, nursing, or bioethics, sounds less individualistic and more emphatic. Nevertheless, care ethics is politically oriented and is neither alternative to, nor disjunctive from, the liberal-democratic conception of state and rights. The appeal to empathy and care cannot rule out or replace the language of rights with the language of needs. Needs are, to a greater or lesser extent, indeterminate. It is obvious that prior to discussing and determining the ends and the purposes of care, the understanding and the interpretation of needs is necessary. An adequate understanding and interpretation of needs entails a chain of other questions about the types of needs at stake, the determination of needs, the prioritization of needs, the actors entitled to identify and balance needs in the resolution of conflicts, and so on. As has been outlined in this paper, such questions may lead to an infinite regress, posing a difficult challenge to an ethics of care. Hearing voices of care does not necessary make democracy better and juster. 
It would be even more harmful to transform moral duties into legal duties. The underlying values within a pluralistic society are too different from each other to be all included and too fundamental to be framed or reduced to (an) ultimate value/s to pursue. The checking and balancing of values, rights, and duties is at the heart of democracy. The reduction to (an) ultimate value/s is not at all the biggest bone of contention; it would be very pernicious and detrimental to a pluralistic democracy. Along with reductions, lurking shadows would fall on democracy.

\section{References}

Amato Mangiameli, A. (2012). (Ed.). Donne, tra storia e politica. Torino, Italy: Giappichelli.

Bilancia, F. (2017). Etica della cura come etica pubblica. Ripensando la democrazia nel contemporaneo. In Paternò, M.P. (Ed.), Cura dell'altro. Interdipendenza e diseguaglianza nelle democrazie contemporanee (pp. 41-65). Napoli, Italy: Editoriale Scientifica.

Bobbio, N. (1969). La funzione promozionale del diritto. In Bobbio, N. (1997). Dalla struttura alla funzione. Nuovi studi di teoria del diritto (pp. 13-32). Milano, Italy: Edizioni di Comunità.

Bobbio, N. (1977). Dalla struttura alla funzione. Nuovi studi di teoria del diritto. Milano, Italy: Edizioni di Comunità.

Bobbio, N. (1995). Il futuro della democrazia. Torino, Italy: Einaudi.

Bobbio, N. (1998). Elogio della mitezza. In Bobbio, N. (2010), Elogio della mitezza e altri scritti morali (pp. 29-47). Milano, Italy: Il Saggiatore.

Bobbio, N. (2000), In praise of meekness. Essays on ethics and politics. Cambridge, UK: Polity Press.

Bobbio, N. (2006). Liberalismo e democrazia. Milano, Italy: Simonelli Editore.

Bobbio, N. (2009). Eguaglianza e libertà. Torino, Italy: Einaudi.

Campbell, L. D. \& Carroll, M. P. (2007). The incomplete devolution: Theorizing gender when when studying men who provide care to aging parents. Men and Masculinities, 9(4), 491-508.

Campesi, G., Populizio, I., Riva, N. (2009). (Eds). Diritto e teoria sociale. Introduzione al pensiero socio-giuridico contemporaneo. Roma, Italy: Carocci.

Card, C. (1990). Caring and evil. Hypatia. A Journal of Feminist Philosophy, 5(1), 101-108.

Casadei, T. (2012), Diritti umani e soggetti vulnerabili. Violazioni, trasformazioni, aporie. Torino, Italy: Giappichelli.

Casadei, T. (2015). Oltre la critica: Appunti per una contemporanea teoria femminista del diritto. Diritto e Questioni Pubbliche, 2, 63-82.

Casadei, T. (2017). Diritto e (dis)parità: Dalla discriminazione di genere alla democrazia paritaria. Roma, Italy: Aracne Editrice. 
Chodorow, N. (1978). Mothering, object-relations, and the female oedipal configuration. Feminist Studies, 4(1), 137-158.

Chodorow, N. (1978). The Reproduction of Mothering: Psychoanalysis and the Sociology of Gender. Berkeley, CA: University of California Press.

Chodorow, N. (2004). Psychoanalysis and women. Annual of Psychoanalysis, 32, 101-129.

Cockburn, P.J.L. (2018). The Politics of Dependance: Economic Parasites and Vulnerable Lives. New York, NY: Palgrave Macmillan.

Facchi, A. (1999). Il pensiero femminista sul diritto: un percorso da Carolo Gilligan a Tove Stang Dahl. In G. Zanetti (Ed.), Filosofi del diritto contemporanei (pp. 129-153). Milano, Italy: Cortina.

Facchi, A. (2013). Breve storia dei diritti umani. Dai diritti dell'uomo ai diritti delle donne. Bologna, Italy: Il Mulino.

Faralli, C. (2012). Women's studies e filosofia del diritto. Rivista di Filosofia del diritto, 2, $297-$ 312 .

Faralli, C. (2015). Donne e diritti. Un'introduzione storica. In T. Casadei (Ed.), Donne, diritto, diritti: Prospettive del giusfemminismo (pp. 1-13). Torino, Italy: Giappichelli.

Fineman, M. (2004). The Authonomy Myth: A Theory of Dependency. New York, NY: The New York Press.

Finemann, M. (2008). The vulnerable subject: Anchoring equality in the human condition. Yale Journal of Law and Feminism, 20(1), 1-23.

Fisher, B., \& Tronto, J. (1991). Toward a feminist theory of caring. In E. Abel \& M. Nelson (Eds.), Circles of Care: Work and Identity in Women's Lives (pp. 36-54). Albany, NY: SUNY Press.

Gilligan, C. (1982). In a Different Voice: Psychological Theory and Womens' Development. Cambridge, MA: Harvard University Press.

Giddens, A. (1990). The Consequences of Modernity. Cambridge, UK: Cambridge Polity Press.

Gilligan, C. (1993). Letter to the readers, 1993. In In a Different Voice (pp. ix-xxvii), Cambridge, MA: Harvard University Press.

Gilligan, C., \& Richards D. A. J. (2009). The Deepening Darkness: Patriarchy, Resistance, and Democracy's Future. New York, NY: Cambridge University Press.

Gilligan, C. (2010). Un regard prospectif à partir du passé. In N. Nurock (Ed.), Carol Gilligan e l'étique du care (pp. 19-38). Paris, France: Puf.

Hankivsky, O. (2006). Imaging ethical globalization: the contribution of a care ethics. Journal of Global Ethics, 2(1), 91-110.

Held, V. (1993). Feminist Morality: Transforming Culture, Society and Politics. Chicago, IL: University of Chicago Press.

Held, V. (2004). Care and justice in a global context. Ratio Juris, 17(2), 141-155.

Held, V. (2006). The Ethics of Care: Personal, Political and Global. New York, NY: Oxford University Press. 
Holmes, S., \& Sunstein, C. (1999). The Cost of Rights: Why Liberty Depends on Taxes. New York, NY: Norton\&Co.

Kelsen, H. (1998). La democrazia. Bologna, Italy: Il Mulino.

Kittay, F. (2008). The global heart transplantat and caring across national boundaries. The Southern Journal of Philosophy, 46, 138-163.

Kittay, E. F., \& Feder E. K. (Eds.), (2002). The Subject of Care: Feminist Perspectives on Dependency. Lanham, MD: Rowman \& Littlefield.

Kohlberg, L. (1958). The Development of Modes of Thinking and Choices in Years 10 to 16 (Doctoral dissertation). Chicago, IL: University of Chicago.

Kohlberg, L. (1976). Moral stages and moralization: The cognitive-development approach. In T. Lickona (Ed.), Moral Development and Behaviour: Theory, Research and Social Issues (pp. 31-53). New York, NY: Holt Rinehart and Winston.

Kohlberg, L. (1981). The Philosophy of Moral Development. San Francisco, CA: Harper and Row.

Larrabee, M. J. (Ed.). (1993). An Ethic of Care: Feminist and Interdisciplinary Perspectives. London, UK: Routledge.

Mackenzie, C., Rogers, W., \& Dodds, S. (Eds.). (2014). Vulnerability: New Essays in Ethics and Feminsit Theory. New York, NY: Oxford University Press.

MacIntyre, A. (1984). After Virtue: A Study in Moral Theory. Notre Dame, IN: University of Notre Dame Press.

Noddings, N. (1984). Caring: A feminine Approach To Ethics and Moral Education. Berkeley, CA: University of California Press.

Noddings, N. (1992). The Challenge to Care in Schools: An Alternative Approach to Education. New York, NY: Teachers College Press.

Noddings, N. (2003). Caring: A Feminine Approach in Ethics and Moral Education. Berkeley, CA: University of California Press.

Noddings, N. (2010). Starting at Home: Caring and Social Policy. Berkeley, CA: University of California Press.

Nussbaum, M. (2001). Upheavals of Thought: The Intelligence of the Emotions. Cambridge, UK: Cambridge University Press.

Okin, S. M. (2004). Reason and Feeling in Thinking about Justice. Vancouver, BC: UBC Press.

Palazzani, L. (2017). Cura e giustizia: Tra teoria e prassi. Roma, Italy: Edizioni Studium.

Paternò. M. P. (2017). (Ed.). Cura dell'altro: Interdipendenza e diseguaglianza nelle democrazie contemporanee. Napoli, Itly: Editoriale Scientifica.

Pitch, T. (1998). Un diritto per due: La costruzione giuridica di genere, sesso e sessualità. Milano, Italy: Il Saggiatore.

Pitch, T. (2004). I diritti fondamentali: Differenze culturali, diseguaglianze sociali, differenza sessuale. Torino, Italy: Giappichelli. 
Plumwood, V. (1993). Feminism and the Mastery of Nature. New York, NY: Routledge.

Puka, B. (1990). The liberation of caring: A different voice from Gilligan's 'Different voice'. $H y$ patia, 1990, 58-82.

Pulcini, E. (2009). La cura del mondo: Paura e responsabilità nell'età globale. Torino: Bollati Boringhieri.

Rachles, J. (1999). The Elements of Moral Philosophy. San Francisco, CA: McGraw-Hill.

Robinson, F. (1999). Globalizing Care: Ethics, Feminist Theory and International Relations. Boulder, CO: Westview Press.

Robinson, F. (2011). The Ethics of Care: A Feminist Approach to Human Society. Philadelphia, PA: Temple University Press.

Rawls, J. (2010). A Theory of Justice. New Delhi, India: Universal Law Publishing Co.

Serpe, A. (2008). The Doubting Philosopher: Norberto Bobbio. Outlines of His Legal Philosophy within Italian Legal Culture. Oslo, Norway: Institutt for offentlig rett.

Serpe, A. (2012). Angelic, brute or responsible rights? I-lex, 16, 129-152.

Serpe, A. (2015). Norberto Bobbio: Un percorso tra legalità e democrazia. In Acocella, G. (Ed.), Materiali per una cultura della legalità (pp. 1-23). Torino, Italy: Giappichelli.

Sevenhuijsen, S. (1998). Citizenship and Ethics of Care: Feminist Considerations on Justice, Morality and Politics. London, UK: Routledge.

Slote, M. (1998). The justice of caring. Social philosophy and policy, 15(1), 171-195.

Slote, M. (2001). Morals from Motives. New York, NY: Oxford University Press.

Slote, M. (2004). Authonomy and empathy. Social Philosophy and Policy, 21, 293-309.

Slote, M. (2006). Moral sentimentalism and moral psychology. In D. Copp (Ed.), The Oxford Handbook of Ethical Theory (pp. 219-239). New York, NY: Oxford University Press.

Slote, M. (2007). The Ethics of Care and Empathy. London, UK: Routledge.

Slote, M. (2015). Care ethics and liberalism. In D. Engster \& M. Hamington (Eds.), Care Ethics and Political Theory. Oxford, UK: Oxford Scolarships Online. Retrieved from https://wpsa.research.pdx.edu/papers/docs/slotemichael.pdf

Tronto, J. (1993). Moral Boundaries: A Political Argument for an Ethic of Care. London, UK: Routledge.

Tronto, J. (1995). Caring as the basis for radical political judgments. Hypatia, 10(2), 141-149.

Tronto, J. (1996). The political concept of care: Feminist reconstructions of traditioanl concepts. In N. J. Hirschmann \& C. Di Stefano (Eds). Revisioning the Political, Feminist Reconstructions of Traditional Concepts in Western Political Theory (pp. 139-156). Boulder, CO: Westview Press.

Tronto, J., \& White, J. A. (2004). Political practices of care: Needs and rights. Ratio Juris, 17(4), 425-453. 
Tronto, J. (2005). Care as the work of citizens: A modest proposal. In M. Friedman (Ed.), Women and citizenship (pp. 130-145). New York, NY: Oxford University Press.

Tronto, J. (2010). Creating caring institutions: Politics, plurality and purpose. Ethics and Social Welfare, 4, 158-171.

Tronto, J. (2011). A feminist democratic ethics of care and global care workers: Citizenship and responsibility. In R. Mahon \& F. Robinson (Eds.), Feminist Ethics and Social Politics: Towards a New Global Political Economy of Care (pp. 162-177). Vancouver, BC: UBC Press.

Tronto, J. (2013a). Caring Democracy: Markets, Equality and Justice. New York, NY: New York University Press.

Tronto, J. (2013b). Democratic care and global responsibilities for care. Retrieved from https://wpsa.research.pdx.edu/papers/docs/Tronto\%20WPSA\%20paper\%202013.pdf

Tronto, J. (2010). Cura e politica democratica: Alcune premesse fondamentali (T. Casadei, Trans.). La società degli individui, 38, 34-42.

Tronto, J. (2015). Who Cares? How to Reshape a Democratic Politics. Ithaca, NY: Cornell University Press.

Tushnet, M. (1984). An essay on rights. Texas Law Review, 62(8), 1363-1403.

Waldron, J. (1996). Rights and needs: The myth of disjunction. In A. Sarat \& T. R. Kearns (Eds.), Legal Rights: Historical and Philosophical Perspectives (pp. 87-109). Ann Arbor, MI: The University of Michigan Press.

Williams, P. (1991). The Alchemy of Race and Rights: Diary of a Law Professor. Cambridge, MA: Harvard University Press. 